\title{
Ecological anatomy of Eugenia punicifolia (Kunth) DC. (MYRTACEAE) in the restinga region, state of Ceará
}

\author{
Viviane de Oliveira Thomaz Lemos ${ }^{1}$, Eliseu Marlônio Pereira de Lucena², \\ Oriel Herrera Bonilla ${ }^{3}$, Bruno Edson-Chaves ${ }^{4}$
}

\begin{abstract}
The species Eugenia punicifolia (Kunth) DC. (myrtle) occurs in the coastal region of the state of Ceará and has ecological and medicinal importance. This study aimed to characterize the leaf anatomy of myrtle (E. punicifolia) in the rainy and dry seasons, as well as in the sun and shade in the restinga region of the state of Ceará and to contribute to the understanding of the morphoanatomic variations in response to the natural conditions of the occurrence of this species. For this, collections of fully expanded leaves were performed at the Botanical Park of Ceará and fixed in FAA70, being replaced by $70 \%$ ethanol after 24 hours. The usual anatomical procedures were then performed in order to qualitatively and quantitatively analyze the leaf blade, petiole and epidermis structures. As a result, it was found that myrtle has xeromorphic characteristics such as thick cuticle, hypoestomatic leaf and sclerenchyma fibers in the median vein vascular bundles. It was concluded that $E$. punicifolia has great plasticity to adjust well under the analyzed conditions. Index terms: Coastal vegetation, myrtle, anatomical plasticity, seasonality, luminosity.
\end{abstract}

\section{Anatomia ecológica foliar da Eugenia punicifolia (Kunth) DC. (MYRTACEAE) na restinga Cearense}

Corresponding author: viviane.7lemos@gmail.com

Received: May 16, 2019 Accepted: Octiber 08, 2019

Copyright: All the contents of this journal, except where otherwise noted, is licensed under a Creative Commons Attribution License.
Resumo- A espécie Eugenia punicifolia (Kunth) DC. (murta) ocorre em região de litoral, no Estado do Ceará, e possui importância ecológica e medicinal. A presente pesquisa objetivou caracterizar a anatomia foliar da murta (E. punicifolia), nas estações de chuva e seca, bem como ao sol e à sombra, na Restinga cearense, pretendendo contribuir para a compreensão das variações morfoanatômicas em resposta às condições naturais de ocorrência da espécie. Para isso, foram realizadas coletas, no Parque Estadual Botânico do Ceará, de folhas totalmente expandidas e fixadas em FAA70, sendo substituído por etanol a 70\%, após 24 horas. Seguiu-se para os procedimentos anatômicos usuais, a fim de analisar qualitativa e quantitativamente as estruturas da lâmina foliar, do pecíolo e da epiderme. Como resultado obteve-se que a murta apresenta características xeromórficas, como cutícula espessa, folha hipoestomática e fibras de esclerênquima nos feixes vasculares da nervura mediana. Portanto, conclui-se que a E. punicifolia possui grande plasticidade por conseguir ajustar-se bem nas condições analisadas.

Termos para indexação: Vegetação litorânea, murta, plasticidade anatômica, sazonalidade, luminosidade. 


\section{Introduction}

Eugenia punicifolia (Kunth) DC. (Myrtaceae), popularly known as myrtle, is a plant commonly found in the coast of Ceará (BRAZ et al., 2004; BFG, 2015; GONÇALVES et al., 2017). It has fruits very appreciated by wild animals and its leaves have compounds with antioxidant, antinoceptive and anti-inflammatory effect (GALENO et al., 2014; BASTING et al., 2014; SILVA; PEDRONE, 2014).

Myrtle is of great importance in the production of seedlings for the recovery of degraded areas and reforestation (PEIXOTO et al., 2015) and has great use potential for agricultural production in polyculture and agroforestry systems as a strategy for food production based on characteristics and potentialities derived from the region's own natural resources (LAMARCA et al., 2013).

Leaf is the plant organ that most readily responds to environmental variations (EVERT, 2013). Leaf anatomy is studied to ensure the identification of species of the same genus, guiding the ideal ecological conditions for the collection of leaves used in the production of natural medicines, and helping to explain the strategies of plants to survive in the various environmental conditions imposed on their habitat (RAMOS et al., 2016; ANDRADE; LAMEIRA, 2017), among them the influence of seasonality and luminosity (PACHECOSILVA; DONATO, 2016; OLIVEIRA et al., 2016; LEMOS et al., 2018).

Generally, species of the genus Eugenia have the following leaf morphoanatomic characteristics: epidermis cells with straight to winding anticlinal walls (DEFAVERI et al., 2011; ESPOSITO-POLESI et al., 2011; DIAS et al., 2012; SÁ et al. , 2016; LEMOS et al., 2018); paracitic stomata found on the abaxial face (DEFAVERI et al., 2011; ESPOSITO-POLESI et al., 2011; DIAS et al., 2012; LEMOS et al., 2018); unistratified epidermis (ESPOSITOPOLESI et al., 2011; SÁ et al., 2016; LEMOS et al., 2018); presence of secretory structures (DONATO; MORRETES, 2009; ESPOSITO-POLESI et al., 2011; SA et al., 2016; LEMOS et al., 2018); and large number of druses (DONATO; MORRETES, 2009; ESPOSITOPOLESI et al., 2011; SÁ et al., 2016).

There is only one study related to the characterization of Eugenia punicifolia leaf anatomy and none applied to ecology (JORGE et al., 2000). Thus, the aim of the present study was to characterize the leaf anatomy of myrtle (E. punicifolia) in the rainy and dry seasons, as well as in the sun and shade in the restinga region of the state of Ceará and to contribute to the understanding of the morphoanatomic variations in response to the natural conditions of the occurrence of this species.

\section{Material and methods}

Collections were performed at the Botanical Park of Ceará $\left(03^{\circ} 42^{\prime} 40.8^{\prime \prime} \mathrm{S}\right.$ and $38^{\circ} 38^{\prime} 40.3^{\prime \prime} \mathrm{W}$ and $29 \mathrm{~m}$ a.s.1.) in ten different $E$. punicifolia populations, of which five are located at the edge of the forest (sun plants) and five within the forest (shade plants) during the rainy (April $/ 16$ - average temperature $34.82^{\circ} \mathrm{C}, 59.8 \%$ average relative humidity and monthly precipitation 277.9 $\mathrm{mm}$ ) and dry seasons (October/16 - average temperature of $36.49^{\circ} \mathrm{C}, 50 \%$ average relative humidity and monthly precipitation of $3.4 \mathrm{~mm}$ ) (FUNCEME, 2019). Fully expanded adult leaves were collected, fixed in FAA70 and after 24 hours the solution was replaced by $70 \%$ ethanol (JOHANSEN, 1940).

Fertile myrtle branches (Eugenia punicifolia (Kunth) DC.) were collected for later taxonomic identification. Species identification occurred through identification keys, comparison with herbarium and standard specimens. The collected material was herborized following usual techniques and later deposited at the "Prisco Bezerra" Herbarium (EAC) of the Federal University of Ceará (UFC), Fortaleza-CE, under Voucher No. 60462-EAC.

Cross sections were performed on the middle third of the leaf blade (border and central vein regions) and petiole using Ranvier microtome. Subsequent steps were: clarification in $20-30 \%$ sodium hypochlorite (KRAUS; ARDUIM, 1997); alcian/safranin blue staining (4:1) (LUQUE et al., 1996); increasing ethanolic series passage; increasing serial passage of Butyl Acetate and mounting on stained glass Varnish (PAIVA et al., 2006).

For analysis of the epidermis, in front view, portions of materials were submitted to Franklin's (1945) solution (with $60 \%$ hydrogen peroxide alteration) for 24 hours in a stove at $80^{\circ} \mathrm{C}$. Paradermic samples were stained with ethanolic safranin (JOHANSEN, 1940) and mounted according to procedures of Paiva et al. (2006).

For photographic recording, a DSC-W530 model camera coupled to BEL PHOTONICS optical microscope was used. For measurements of the anatomical structures, the Image-Pro Plus software was used.

For cross-sections in the leaf margin region, thickness of the leaf blade, mesophyll, cuticle and epidermis on the abaxial and adaxial face were quantitatively evaluated $(\mathrm{n}=30)$, as well as the palisade and lacunous parenchyma. In the central vein and leaf petiole region, total length and width, central vascular bundle area and druses count were measured. In the petiole, secretory cavities were also quantified and their area was measured.

In paradermic sections, for the abaxial face, length, width and area of each stomata were quantitatively examined $(n=30)$, as well as density, average frequency and stomatal index (IE), the latter based on the Willmer and Fricker's formula (1996). 
The experimental design was completely randomized, with 2 (rainy and dry) x 2 (sun and shade) factorial and 30 replicates. Results were submitted to normality test, followed by analysis of variance observing the significance by the $\mathrm{F}$ test and when significant, the Tukey test was performed at 5\% probability level (SANTOS et al., 2008). The t-test at $1 \%$ probability level was also performed for cuticle and epidermis thickness (VIEIRA, 2011).
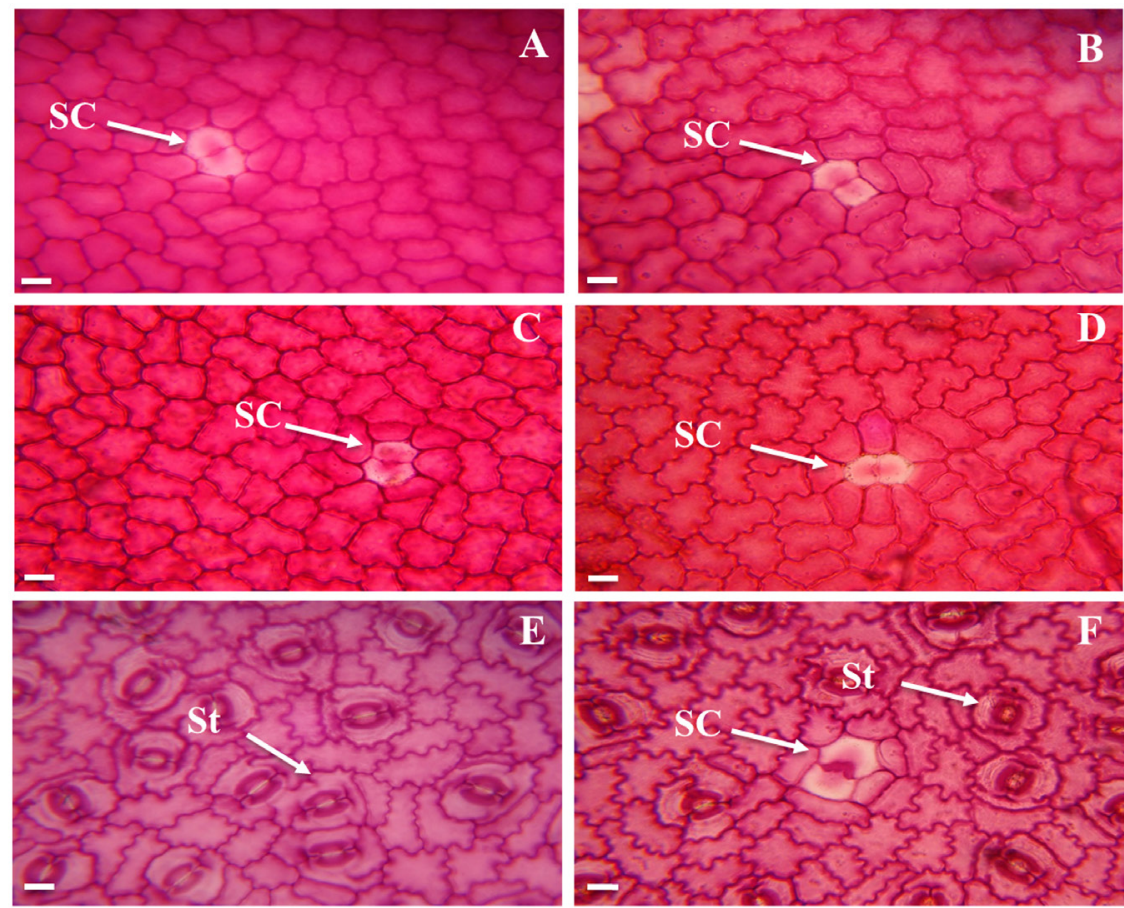

\section{Qualitative characteristics}

The qualitative morphoanatomic characteristics showed no differences in the different luminosity and seasonal conditions.

The adaxial face of the epidermis of E. punicifolia leaves presents cells with sinuous walls (Figures 1A-D). Epidermal cells located above the secretory cavities are easily recognizable by the presence of two colorless polygonal cells around which adjacent cells are often circular in shape (Figure 1J).

Common epidermal cells of the abaxial face have sinuous anticlinal walls and paracitic stomata (Figures 1E and I). Epidermal cells under secretory cavities are similar to those described for the adaxial face (Figures $1 \mathrm{~F}$ and $\mathrm{G}$ ).
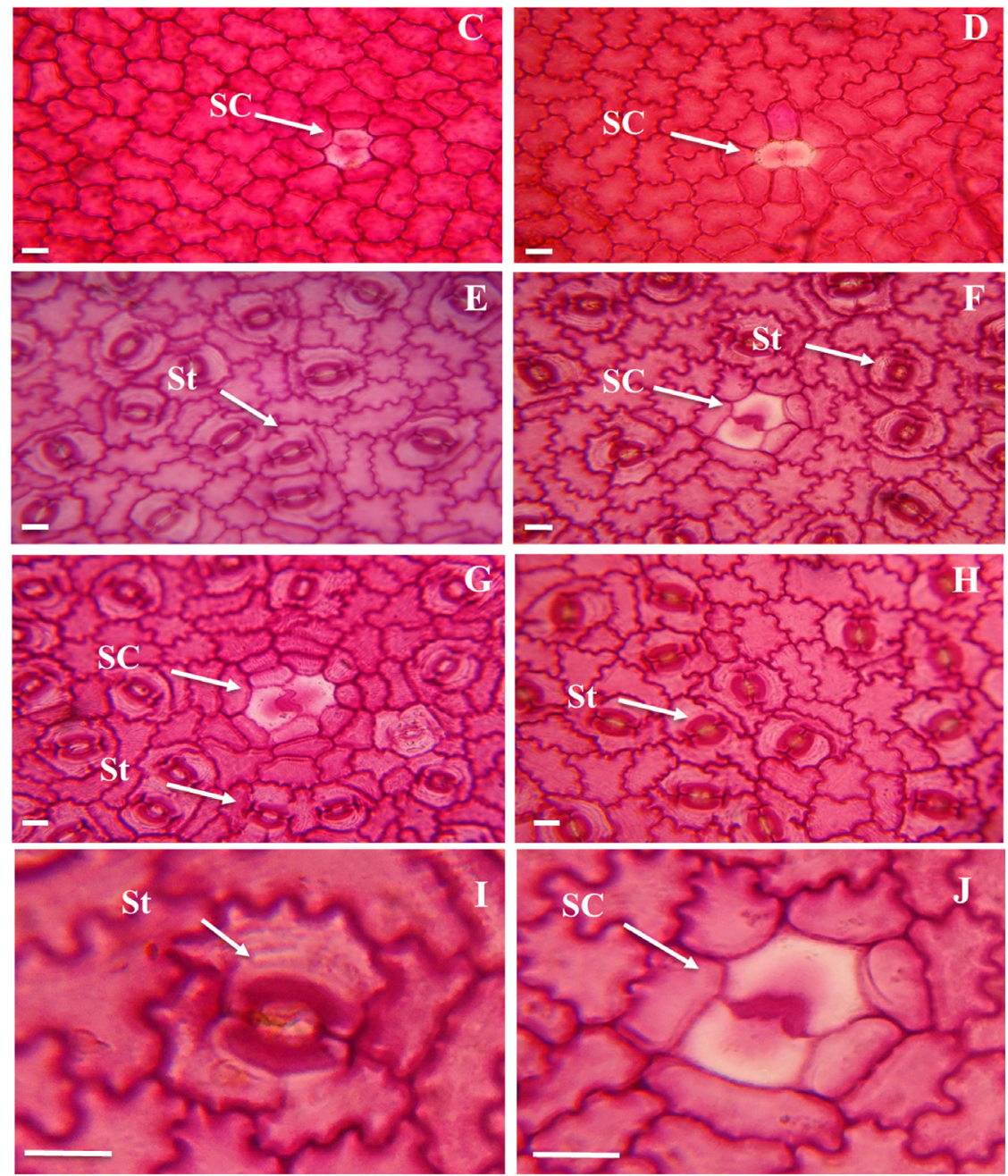

Figure 1 - Adaxial (A-D) and abaxial (E-H) epidermis of Eugenia punicifolia (Kunth) DC leaves in front view. Treatments: A and E- rainy/sun; B and F- rainy/shade; C and G- dry/sun; D and H- dry/shade; I- detail of the abaxial epidermis showing a stoma; J- detail of the adaxial epidermis showing a secretory cavity under two colorless cells. Abbreviation: SC- secretory cavity; St- stomata. Bar: $30 \mu \mathrm{m}$. 
The epidermis of both faces is unistratified with a thick cuticle (Figures 2A-D). Stomata are at the same level as other common epidermal cells (Figure 2E).

The leaf blade is linear and dorsiventral (Figure 2AD). Under all conditions tested, the palisade parenchyma (PP) presents 1-2 cell layers. The lacunous parenchyma (PL) is formed by 6-8 cell strata, which delimit large
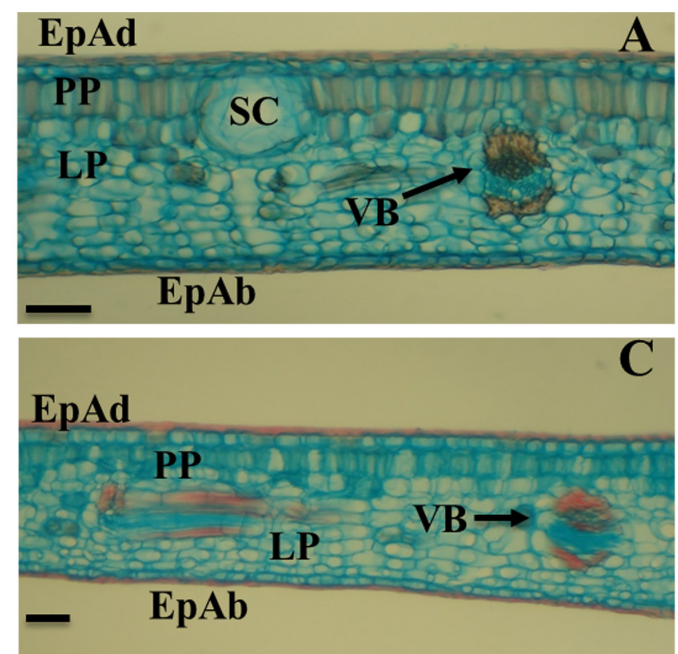

C
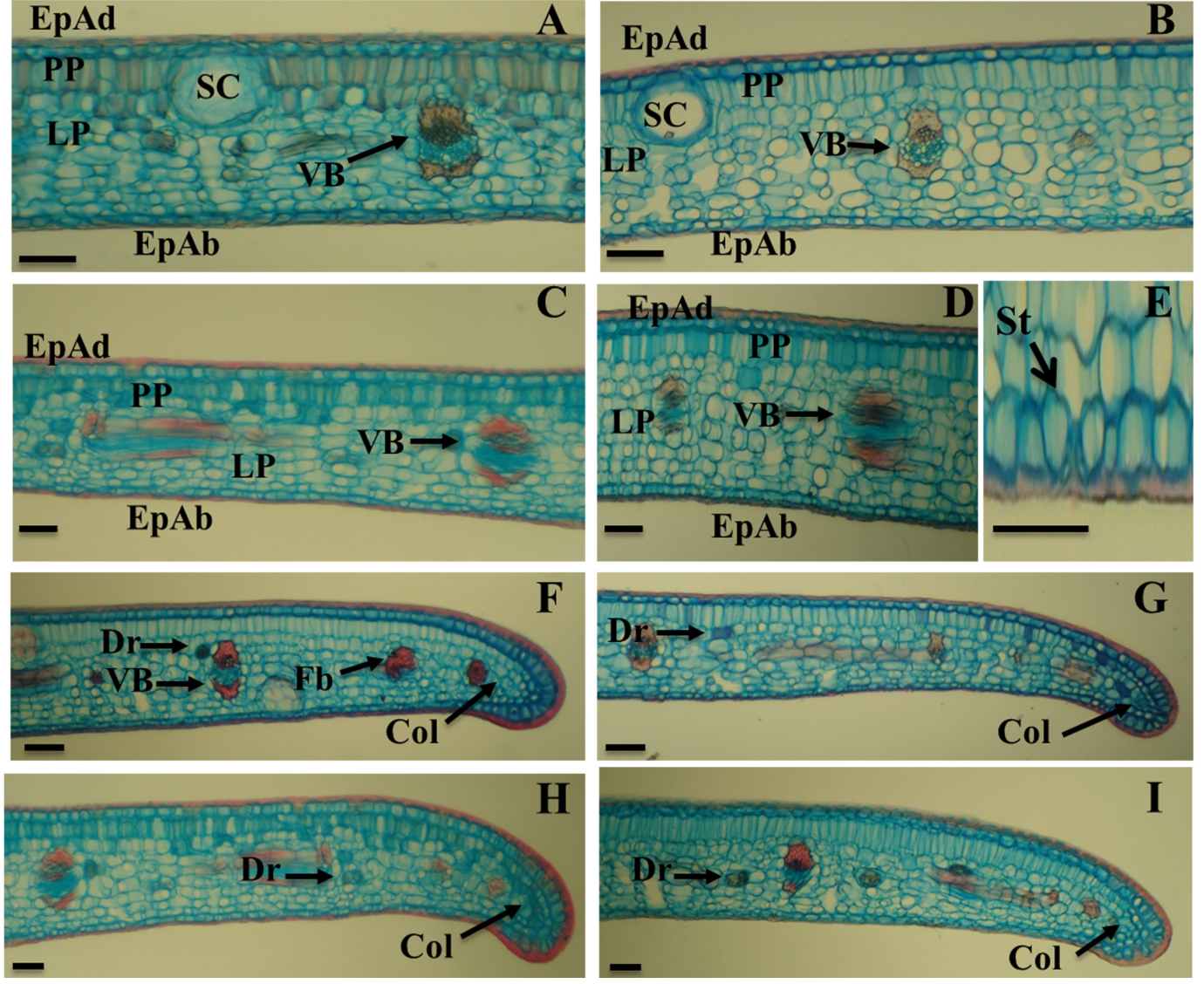

Figure 2 - Cross-section of Eugenia punicifolia (Kunth) DC. leaves. Treatments: A and F- rainy/sun; B and G- rainy/ shade; C and H- dry/sun; D and I- dry/shade. E- detail showing stomata. Abbreviations: Dr - druse; Col- collenchyma; SC- secretory cavity; EpAd- epidermis adaxial; EpAb- epidermis abaxial; St- Stomata; VB- vascular bundle; PPpalisade parenchyma; LP- lacunous parenchyma; Fb- fibers. Bar: $60 \mu \mathrm{m}$, except in figure $\mathrm{E}$ where bar is $30 \mu \mathrm{m}$.

The foliar border region is slightly flexed to the abaxial face in the distal region (Figures 2F-I). PP is disrupted in the distal region of the border and the number of PL cell strata is reduced to about four, in which annular collenchyma is also evident. Near the distal region of the border, a small set of sclerenchymatic fibers may occur (Figure F).

The median vein region is biconvex in shape (Figures 3A-D). PP is interrupted by 2-6 colenchymatic cell layers, which make contact with the fibers of the vascular system. The open arch bicolateral vascular bundle faces slightly towards the adaxial face. Below the bundle, 3-6 parenchyma and 1-2 collenchyma layers are found just above the epidermis abaxial face cells. In the central vein, it is still possible to verify the presence of idioblasts with druses in the parenchyma cells and phloem.
The median region of the petiole in the cross section is concave on the adaxial face and convex on the abaxial face (Figures 3E-H). The epidermis is unistratified, with unicellular tectoral trichomes only on the adaxial face. There are 2-6 collenchyma layers in the subepidermal region. The cortical region consists of a parenchyma, with 8-10 layers facing the adaxial face and approximately 10 layers facing the abaxial face. Secretory cavities occur near the collenchyma. The central portion of the petiole consists of an arc-shaped beam. The organization of the vascular system is similar to the median vein, differing for presenting more involute open arch margins in the petiole and absence of marginal fibers. Druses are common in the cortex and phloem. 

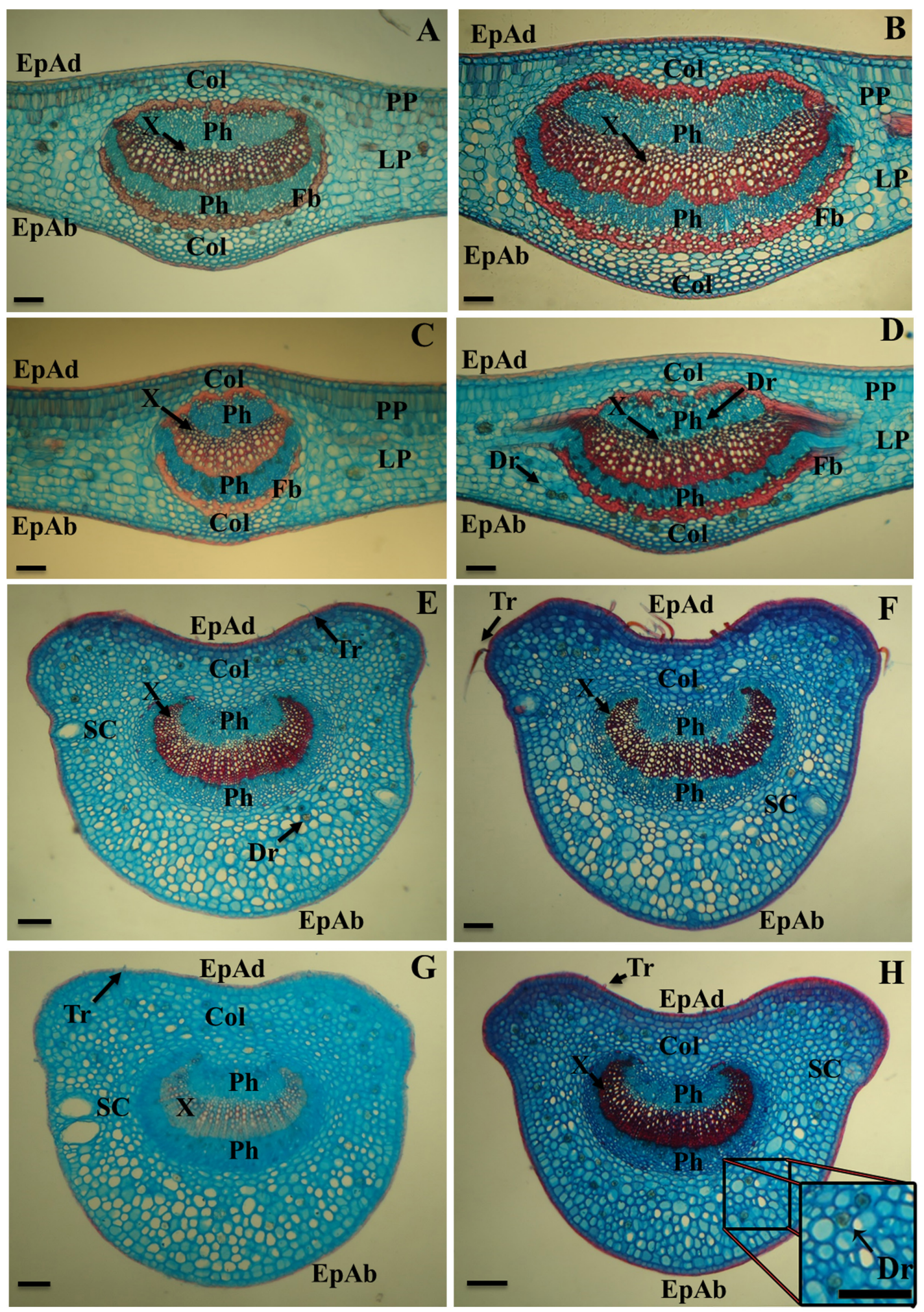

Figure 3 - Median vein and petiole in cross section, of Eugenia punicifolia (Kunth) DC. Treatments: A and E- rainy/ sun; B and F- rainy/shade; C and G- dry/sun; D and H- dry/shade. Abbreviations: Col- collenchyma; Dr - druse; SC- secretory cavity; EpAd- epidermis adaxial; EpAb- epidermis abaxial; fb- fibers sclerenchymatic; Ph - Phloem; LP- lacunous parenchyma; PP- palisade parenchyma; Tr- Trichrome; X-xylem. Bar: $160 \mu \mathrm{m}$. 


\section{Quantitative characteristics}

The quantitative analysis of paradermic sections was performed for the abaxial leaf face since it is hypoestomatic (Table 1). Stomatal density showed differences only in relation to luminosity, being higher in sun leaves. Stomatal index and frequency presented statistical difference only in relation to the season, both being higher in the rainy season. Stomatal length did not present statistical difference in the analyzed treatments. Stomatal area and width were larger in the dry season compared to the rainy season. Stomatal width presented significant differences in luminosity, being larger in shade leaves.

Table 1 - Quantitative parameters of cross sections of Eugenia punicifolia (Kunth) DC. leaves in the rainy and dry seasons, as well as in the sun and shade.

\begin{tabular}{ccccc}
\hline \multirow{2}{*}{ Parameters } & \multicolumn{2}{c}{ Season } & \multicolumn{2}{c}{ Luminosity } \\
\cline { 2 - 5 } & Rainy & Dry & Sun & Shade \\
\hline Stomatal density & $54.16 \mathrm{a}$ & $56.66 \mathrm{a}$ & $61.33 \mathrm{a}$ & $49.50 \mathrm{~b}$ \\
Stomatal frequency & $0.13 \mathrm{a}$ & $0.11 \mathrm{~b}$ & $0.12 \mathrm{a}$ & $0.12 \mathrm{a}$ \\
Stomatal index & $11.50 \mathrm{a}$ & $10.55 \mathrm{~b}$ & $11.31 \mathrm{a}$ & $10.74 \mathrm{a}$ \\
Stomatal length $(\mu \mathrm{m})$ & $31.61 \mathrm{a}$ & $31.99 \mathrm{a}$ & $31.86 \mathrm{a}$ & $31.73 \mathrm{a}$ \\
Stomatal width $(\mu \mathrm{m})$ & $25.07 \mathrm{~b}$ & $33.07 \mathrm{a}$ & $25.68 \mathrm{~b}$ & $32.46 \mathrm{a}$ \\
Stomatal area $\left(\mu \mathrm{m}^{2}\right)$ & $109.53 \mathrm{~b}$ & $120.97 \mathrm{a}$ & $115.41 \mathrm{a}$ & $115.09 \mathrm{a}$ \\
\hline
\end{tabular}

Average followed by the same letter in seasons or luminosity does not differ statistically from each other by the Tukey test at $5 \%$ probability level. There is no interaction between seasons and luminosity.

In the adaxial face of cross-sections, the epidermis thickness showed statistical difference only in luminosity, being higher in sun leaves; the cuticle was thicker in the rainy season and in sun leaves (Table 2). These parameters also presented interaction between treatments so that the highest thicknesses were found for rainy/sun and the lowest for rainy/shade (Table 3).

Table 2 - Quantitative parameters of cross-sections of Eugenia punicifolia (Kunth) DC leaves in the rainy and dry seasons, as well as in the sun and shade.

\begin{tabular}{ccccc}
\hline Parameters & \multicolumn{2}{c}{ Season } & \multicolumn{2}{c}{ Luminosity } \\
\cline { 2 - 5 } & Rainy & Dry & Sun & Shade \\
\hline Epidermis adaxial $(\mu \mathrm{m})^{*}$ & $30.94 \mathrm{a}$ & $29.54 \mathrm{a}$ & $31.64 \mathrm{a}$ & $28.85 \mathrm{~b}$ \\
Epidermis abaxial $(\mu \mathrm{m})^{*}$ & $17.89 \mathrm{a}$ & $17.58 \mathrm{a}$ & $17.89 \mathrm{a}$ & $17.58 \mathrm{a}$ \\
Adaxial cuticle $(\mu \mathrm{m})^{*}$ & $14.32 \mathrm{a}$ & $13.10 \mathrm{~b}$ & $14.36 \mathrm{a}$ & $13.07 \mathrm{~b}$ \\
Abaxial cuticle $(\mu \mathrm{m})^{*}$ & $9.20 \mathrm{a}$ & $8.59 \mathrm{a}$ & $8.94 \mathrm{a}$ & $8.84 \mathrm{a}$ \\
Leaf blade $(\mu \mathrm{m})^{*}$ & $258.48 \mathrm{a}$ & $233.03 \mathrm{~b}$ & $257.70 \mathrm{a}$ & $233.82 \mathrm{~b}$ \\
Mesophyll $(\mu \mathrm{m})^{*}$ & $207.00 \mathrm{a}$ & $179.98 \mathrm{~b}$ & $205.61 \mathrm{a}$ & $181.37 \mathrm{~b}$ \\
Palisade parenchyma $(\mu \mathrm{m})^{*}$ & $72.75 \mathrm{a}$ & $60.45 \mathrm{~b}$ & $70.76 \mathrm{a}$ & $62.44 \mathrm{~b}$ \\
Lacunous parenchyma $(\mu \mathrm{m})^{*}$ & $133.22 \mathrm{a}$ & $119.34 \mathrm{~b}$ & $134.14 \mathrm{a}$ & $118.42 \mathrm{~b}$ \\
Central vein length $(\mu \mathrm{m})$ & $566.59 \mathrm{a}$ & $516.14 \mathrm{~b}$ & $519.91 \mathrm{~b}$ & $562.83 \mathrm{a}$ \\
Central vein width $(\mu \mathrm{m})$ & $663.28 \mathrm{a}$ & $581.30 \mathrm{~b}$ & $568.71 \mathrm{~b}$ & $675.87 \mathrm{a}$ \\
Central vein vascular bundle area $\left(\mu \mathrm{m}^{2}\right)$ & $1666.89 \mathrm{a}$ & $1485.60 \mathrm{~b}$ & $1449.17 \mathrm{~b}$ & $1703.33 \mathrm{a}$ \\
Amount of druses in the central vein & $30.66 \mathrm{a}$ & $35.71 \mathrm{a}$ & $30.85 \mathrm{a}$ & $35.53 \mathrm{a}$ \\
Petiole length $(\mu \mathrm{m})$ & $1481.60 \mathrm{a}$ & $1318.37 \mathrm{~b}$ & $1330.00 \mathrm{~b}$ & $1469.97 \mathrm{a}$ \\
Petiole width $(\mu \mathrm{m})$ & $1297.23 \mathrm{a}$ & $1173.93 \mathrm{~b}$ & $1200.46 \mathrm{~b}$ & $1270.70 \mathrm{a}$ \\
Petiole vascular bundle area $\left(\mu \mathrm{m}^{2}\right)$ & $2671.89 \mathrm{a}$ & $2459.47 \mathrm{~b}$ & $2404.87 \mathrm{~b}$ & $2726.49 \mathrm{a}$ \\
Amount of druses in the petiole* & $114.48 \mathrm{a}$ & $97.73 \mathrm{~b}$ & $104.30 \mathrm{a}$ & $107.91 \mathrm{a}$ \\
Amount of secretory cavities in the petiole & $0.90 \mathrm{a}$ & $0.81 \mathrm{a}$ & $0.8333 \mathrm{a}$ & $0.83 \mathrm{a}$ \\
Petiole secretory cavities area $\left(\mu \mathrm{m}^{2}\right)$ & $486.07 \mathrm{a}$ & $442.31 \mathrm{~b}$ & $453.49 \mathrm{a}$ & $474.90 \mathrm{a}$ \\
\hline
\end{tabular}

Average followed by the same letter in seasons or luminosity does not differ statistically from each other by the Tukey test at $5 \%$ probability level. Asterisk indicates that there is interaction between seasons and luminosity, more details in Table 3 . 
In the abaxial face of cross-sections, cuticle and epidermis thickness did not show significant differences for luminosity and season; both are thinner than in the adaxial region (Table 2). However, for these parameters there was interaction between treatments, in which cuticle and epidermis thickness of the abaxial face were higher in the rainy/sun treatment; for cuticle, the lowest values were found in the dry/sun; and for the epidermal cells, the lowest thicknesses were found in the rainy/shade and dry/sun (Table 3).
The leaf blade, mesophyll, palisade and lacunous parenchyma show greater thickness in the rainy season and in the sun (Table 2). These parameters show interaction between treatments so that the highest thicknesses were found for the rainy/sun and the lowest in the dry/sun (Table 3).

Table 3- Quantitative parameters of Eugenia punicifolia (Kunth) DC leaves of results that showed interaction between season and luminosity.

\begin{tabular}{|c|c|c|c|c|c|}
\hline \multirow{2}{*}{ Season } & \multicolumn{2}{|c|}{ Luminosity } & \multirow{2}{*}{ Season } & \multicolumn{2}{|c|}{ Luminosity } \\
\hline & Sun & Shade & & Sun & Shade \\
\hline Epidermis adaxial $(\mu m)$ & & & Epidermis abaxial $(\mu m)$ & & \\
\hline Rainy & $34.02 \mathrm{aA}$ & $27.86 \mathrm{aB}$ & Rainy & $18.85 \mathrm{aA}$ & $16.93 \mathrm{aB}$ \\
\hline Dry & $29.25 \mathrm{bA}$ & $29.84 \mathrm{aA}$ & Dry & $16.93 \mathrm{bA}$ & $18.23 \mathrm{aA}$ \\
\hline Adaxial cuticle $(\mu m)$ & & & Abaxial cuticle $(\mu \mathrm{m})$ & & \\
\hline Rainy & $16.01 \mathrm{aA}$ & $12.64 \mathrm{aB}$ & Rainy & $9.78 \mathrm{aA}$ & $8.62 \mathrm{aA}$ \\
\hline Dry & $12.70 \mathrm{bA}$ & $13.50 \mathrm{aA}$ & Dry & $8.11 \mathrm{bA}$ & $9.06 \mathrm{aA}$ \\
\hline Leaf blade $(\mu m)$ & & & Mesophill ( $\mu m)$ & & \\
\hline Rainy & $280.65 \mathrm{aA}$ & $236.32 \mathrm{aB}$ & Rainy & $226.26 \mathrm{aA}$ & $187.74 \mathrm{aB}$ \\
\hline Dry & $234.74 \mathrm{bA}$ & $231.31 \mathrm{aA}$ & Dry & $184.96 \mathrm{bA}$ & $175.00 \mathrm{aA}$ \\
\hline Palisade parenchyma $(\mu \mathrm{m})$ & & & Lacunous parenchyma $(\mu m)$ & & \\
\hline Rainy & $81.44 \mathrm{aA}$ & $64.07 \mathrm{aB}$ & Rainy & $145.96 \mathrm{aA}$ & $120.48 \mathrm{aB}$ \\
\hline Dry & $60.08 \mathrm{bA}$ & $60.82 \mathrm{aA}$ & Dry & $122.33 \mathrm{bA}$ & $116.36 \mathrm{aA}$ \\
\hline Amount of druses in the petiol & & & & & \\
\hline Rainy & $102.60 \mathrm{aB}$ & $126.36 \mathrm{aA}$ & & & \\
\hline Dry & $106.00 \mathrm{aA}$ & $89.46 \mathrm{bA}$ & & & \\
\hline
\end{tabular}

Means followed by the same uppercase letter in the row and lowercase in the column do not differ statistically by the Tukey's test at $5 \%$ probability level.

Length, width and area of the central vein were higher in leaves collected in the rainy season and under shade, with no interaction between treatments. The number of druses in the median vein did not present statistical differences (Table 2).

Length, width and area of the petiole vascular bundle were higher in the rainy season and in shade leaves. The number of druses presented statistical difference only in relation to the season, showing higher amount in the rainy season (Table 2), with interaction between treatments, with higher values in the rainy/shade period and lower values in the dry/shade period (Table 3 ). There was no statistical difference in the amount of secretory cavities found in the petiole, but its area showed difference according to the season of the year, being larger in the rainy season (Table 2).

\section{Discussion}

\section{Qualitative characteristics}

Eugenia punicifolia presented characteristics common to Myrtaceae, such as hypostomatic leaf, occurrence of secretory cavities, bicolateral vascular bundle, presence of druses (METCALFE; CHALK, 1979) and dorsiventral mesophyll common to other species of the family (PACHECO-SILVA; DONATO, 2016; RETAMALES et al., 2014). It also has characteristics similar to the genus Eugenia L., such as: sinuous contour epidermal cells (DEFAVERI et al., 2011; ESPOSITOPOLESI et al., 2011; DIAS et al., 2012; SÁ et al., 2016); concave-shaped petiole with secretory cavities near the collenchyma and large amount of druses (DONATO; MORRETES, 2009; ESPOSITO-POLESI et al., 2011; SÁ et al., 2016). 
A study by Donato and Morretes (2009) with $E$. florida DC. showed that epidermal cells have sinuous shape, especially in sun leaves; however, the species of the present study showed greater sinuosity in shade leaves.

Hypoestomatic leaves provide greater water savings, being an advantage for plants that live in environments with abundant light and periods of water deficit (ESPOSITO-POLESI et al., 2011), as the plant under study.

Druses may help to protect, as they reduce the digestibility of leaf tissue by herbivores and help to distribute solar radiation among cells (LARCHER, 2001; FERREIRA et al., 2015). Druses are usually formed of calcium oxalate, and their function is to facilitate the transport of sugars, since calcium can inhibit some stages of sugar formation (VEZZA et al., 2006). The species under study presented druses in the phloem, which may have been a way of facilitating the transport of elaborated sap.

The secretory cavities of subepidermal occurrence distributed in both leaf blade faces found in the present study have already been described for Myrtaceae, (METCALFE; CHALK, 1979). These structures can store chemicals such as terpenes or carbohydrates and other substances (EVERT, 2013).

The foliar border region slightly flexed to the myrtle abaxial region was also found for Eugenia rotundifolia (Arn.) by Defaveri et al. (2011).

The vascular bundle of the median vein characterized as bicolateral, forming an arch with opening facing the adaxial face, was also found for other species of the genus (ESPOSITO-POLESI et al., 2011; SÁ et al., 2016).

The concave-convex shape of the petiole found for myrtle in the present study is common to other species of the genus Eugenia L. with secretory cavities near the collenchyma and large number of druses (DONATO; MORRETES, 2009; ESPOSITO-POLESI et al., 2011; SA et al., 2016).

\section{Quantitative characteristics}

Stomata may vary in leaves in distribution, size, shape, quantity and frequency (SUTCLIFFE, 1980; WILLMER; FRICKER, 1996; LARCHER, 2001). The stomatal index is mainly affected by humidity, being more advantageous to be higher in the rainy season, as it helps to increase the stomatal, transpiratory and photosynthetic conductance rate, which are necessary mechanisms for plants to produce substances required for their metabolism (SILVA et al., 2005).

Light intensity is the main abiotic determinant that exerts great influence on leaf modification (LARCHER; BOEGER, 2009). Donato and Morretes (2009) reported that the stomatal density for Eugenia is higher in sun leaves. This feature was also observed by Boeger et al. (2009) in medicinal plants, as verified in the present study.
Reduced stomata are a form of adaptation to the dry season, as they allow plants to regulate transpiration more efficiently (FAHN; CUTLER, 1992), but the species of the present study showed smaller stomata in the rainy season.

Leaves can easily modify their internal structure according to environmental variations, such as water deficit and high light intensity, which may end up inducing xeromorphism (AMORIM; MELO JÚNIOR, 2017; EVERT, 2013), such as increased cuticle thickness, vascular area and abundance of sclerenchymatic fibers (MENEZES; SILVA; PINNA, 2006); The latter, in myrtle, was commonly observed associated with central vein vascular bundles. However, the aforementioned pattern for xerophyte plants was not observed for the plant under study, especially petiole vascular bundle and central vein area, which were more abundant in the rainy season and under shade.

The greater thickness of the leaf blade, palisade and lacunous parenchyma in sun leaves corroborates Boeger et al (2009). The palisade parenchyma tends to become thicker as light exposure increases (AMORIM; MELO JR, 2017), accentuating the photosynthetic potential of sun leaves (EVERT, 2013). The lacunous parenchyma also helps to increase the photosynthetic rate due to its large intercellular spaces, favoring the absorption of carbon dioxide (MENEZES; SILVA; PINNA, 2006).

The thickness of the median vein was higher in shaded environments, a fact not verified in the work of Dardengo et al. (2017). The greater petiole length in shadow leaves found for the species under study may be because this structure aids in the projection of leaves for greater light absorption (LARCHER; BOEGER, 2009).

\section{Conclusions}

Only the quantitative characteristics showed morphoanatomic differences in the different seasonal (rainy and dry) and luminosity conditions (sun and shade).

For seasonality, most parameters were higher during the rainy season, except for width and stomatal area, which were higher during the dry season; and stomatal density and length, adaxial and abaxial epidermis, abaxial cuticle, amount of druses in the central vein and petiole, which did not show significant differences.

Regarding luminosity, most parameters showed no significant differences, except for stomatal density, adaxial epidermis, adaxial cuticle, leaf blade, mesophyll, palisade and lacunous parenchyma, which were higher in sun leaves; and stomatal width, central vein length and width, central vein vascular bundle area, petiole length and width, and petiole vascular bundle area, which were higher in shade leaves. 
Interaction between seasonality and luminosity in relation to adaxial and abaxial epidermis, adaxial and abaxial cuticle, leaf blade, mesophyll, palisade and lacunous parenchyma thickness, and amount of druses in the petiole was also observed.

Finally, different adaptive strategies of the leaf anatomy of E. punicifolia are observed to adjust to the adverse environmental conditions, revealing the great phenotypic plasticity of this species.

\section{Acknowledgments}

The authors would like to thank the Foundation for Scientific and Technological Development Support of Ceará (FUNCAP) for granting the Master's Scholarship to the first author and to Botanical State Park of Ceará for logistical support.

\section{References}

AMORIM, W.; MELO JÚNIOR, J.C.F. de. Plasticidade morfoanatômica foliar de Tibouchina clavata (Melastomataceae) ocorrente em duas formações de restinga. Rodriguésia, Rio de Janeiro, v.68, n.2, p.545$555,2017$.

ANDRADE, C.R.S.; LAMEIRA, O.A. Padrão de venação de Psychotria ipecacuanha (Brotero) Stokes (Rubiaceae). Revista Trópica - Ciências Agrárias e Biológicas, Chapadinha, v.9, n.1, p.104-110, 2017.

BASTING, R.T.; NISHIJIMA, C.M.; LOPES, J.A.; SANTOS, R.C.; PÉRICO, L.L.; LAUFER, S.; BAUER, S.; COSTA, M.F.; SANTOS, L.C.; ROCHA, L.R.M.; VILEGAS, W.; SANTOS, A.R.S.; SANTOS, C. DOS; HIRUMA-LIMA, C.A.Antinociceptive, anti-inflammatory and gastroprotective effects of a hydroalcoholic extract from the leaves of Eugenia punicifolia (Kunth) DC. in rodents. Journal of Ethnopharmacology, Pretoria, v.157, n. 18, p.257-267, 2014.

BFG. Growing knowledge: an overview of seed plant diversity in Brazil. Rodriguésia, Rio de Janeiro, v.66, n.4, p.1085-1113, 2015.

BOEGER, M.R.T.; ESPÍNDOLAJÚNIOR,A.; MACCARI JÚNIOR, A.; REISSMANN, C.B.; ALVES, A.C.A.; RICKLI, F.L. Variação estrutural foliar de espécies medicinais em consórcio com erva-mate, sob diferentes intensidades luminosas. Floresta, Curitiba, v.39, n.1, p.215-225, 2009.
BRAZ, D.M.; MOURA, M.V.L.P.; ROSA, M.M.T. Chave de identificação para as espécies de dicotiledôneas arbóreas da Reserva Biológica do Tinguá, RJ, com base em caracteres vegetativos. Acta Botânica Brasílica, Belo Horizonte, v.18, n.2, p.225-240, 2004.

DARDENGO, J.F.E.; ROSSI, A.A.B.; SILVA, I.V.; PESSOA, M.J.G.; SILVA, C.J. Análise da influência luminosa nos aspectos anatômicos de folhas de Theobroma speciosum Willd ex Spreng. (Malvaceae). Ciência Florestal, Santa Maria, v.27, n.3, p.843-851, 2017.

DEFAVERI, A.C.A.; ARRUDA, R.C.O.; SATO, A. Leaf anatomy and morphology of Eugenia rotundifolia applied to the authentication of the "abajurú" commercially sold.

Revista Brasileira de Farmacognosia, Curitiba, v.21, n.3, p.373-381, 2011.

DIAS, C.N.; RODRIGUES, K.A.F.; RESPLANDES, S.M.; AGUIAR, L. dos R.; AMARAL, F.M.M.; MORAES, D.F.C. Caracterização farmacobotânica das folhas de Eugenia uniflora L. (Myrtaceae) coletadas em São Luís-MA, BRASIL. Revista de Ciências da Saúde, São Luís, v.14, n.2, p.95-102, 2012.

DONATO, A.M.; MORRETES, B.L. Anatomia foliar de Eugenia florida DC. (Myrtaceae). Revista Brasileira de Farmacognosia, Curitiba, v.19, n.3, p.759-770, 2009.

ESPOSITO-POLESI, N.P.; RODRIGUES, R.R.; ALMEIDA, M. Anatomia ecológica da folha de Eugenia glazioviana KIAERSK (Myrtaceae). Revista Árvore, Viçosa, MG, v.35, n.2, p.255-263, 2011.

EVERT, R.F. Anatomia das plantas de Esau: meristemas, células e tecidos do corpo da planta: sua estrutura, função e desenvolvimento. 3.ed. São Paulo: Blucher, 2013. 728p.

FAHN, A., CUTLER, D.F. Xerophytes. Berlin: Gebüder Borntraeger, 1992. 185p.

FERREIRA, C.S.; CARMO, W.S.; GRACIANORIBEIRO, D.; OLIVEIRA, J.M.F.; MELO, R.B.; FRANCO, A.C. Anatomia da lâmina foliar de onze espécies lenhosas dominantes nas savanas de Roraima. Acta Amazônica, Petrópoles, v.45, n.4, p.337-346, 2015 .

FRANKLIN, G.L. Preparation of thin sections of synthetic resins and wood-resin composites and a new macerating method for wood. Nature, Basingstoke, v.51, n.1, p.3924, 1945. 
FUNCEME - Fundação Cearense de Meteorologia e Recursos Hídricos. Caléndário das chuvas do Estado do Ceará. Fortaleza, 2019. Disponível em: http://www. funceme.br/app/calendario/produto/municipios/maxima/ mensal. Acesso em: 23 set. 2019.

GALENO, D.M.L.; CARVALHO, R.P.; BOLETI, A.P.A.; LIMA, A.S.; ALMEIDA, P.D.O.; PACHECO, C.C.; SOUZA, T.P.; LIMA, E.S. Extract from Eugenia punicifolia is an antioxidant and inhibits enzymes related to metabolic syndrome. Applied Biochemistry and Biotechnology, London, v. 172, n.1, p.311-324, 2014.

GONÇALVES, N.P.; LUCENA, E.M.P.; BONILLA, O.H.; TAVARES, F.J.C. Physicochemical composition of native fruits of the Ceará coast at different development stages. Revista Brasileira de Engenharia Agrícola e Ambiental, Campina Grande, v.21, n.9, p.640-644, 2017.

JOHANSEN, D.A. Plant microtechnique. New York: McGraw Hill, 1940. 523p.

JORGE, L. I. F.; AGUIAR, J. P. L.; SILVA, M. L. P. Anatomia foliar de pedra-hume-caá (Myrcia sphaerocarpa, Myrcia guianensis, Eugenia punicifolia - Myrtaceae. Acta Amazonica, v.30, n.1, p.49-57, 2000.

KRAUS, J.E., ARDUIN, M. Manual básico de métodos em morfologia vegetal. Rio de Janeiro: Editora da Universidade Federal Rural do Rio de Janeiro, 1997. $198 p$.

LAMARCA, E.V.; BAPTISTA, W.; RODRIGUES, D.S.; OLIVEIRA JÚNIOR, C.J.F. Contribuições do conhecimento local sobre o uso de Eugenia spp. em sistemas de policultivos e agroflorestas. Revista Brasileira de Agroecologia, Rio de Janeiro, v.8, n.3, p.119-130, 2013.

LARCHER, L.; BOEGER, M.R.T. Arquitetura foliar de Odontonema strictum (Nees) O. Kuntze (Acanthaceae) em duas condições de luminosidade. Hoehnea, São Paulo, v.36, n.2, p.321-327, 2009.

LARCHER, W. Ecofisiologia vegetal. 2. ed. São Carlos: Rima, 2001. 531p.

LEMOS, V.O.T.; LUCENA, E.M.P.; BONILLA, O.H.; EDSON-CHAVES, B.; SAMPAIO, V.S. Ecological anatomy of Eugenia luschnathiana (O.Berg) Klotzsch ex B.D.Jacks. (Myrtaceae) leaves in the Restinga region, state of Ceara. Revista Brasileira de Fruticultura, Jaboticabal, v.40, n.5, p.1-14, 2018.
LUQUE, R.; SOUSA, H.C.; KRAUS, J.E. Métodos de coloração de Roeser (1972) - modificado - e Kropp visando a substituição do azul de astra por azul de alcião GS ou GX. Acta Botânica Brasílica, Belo Horizonte, v.10, n.2, p.199-212, 1996.

MENEZES, N.L.; SILVA, D.C.; PINNA, G.F.A.M. Folha. In: APEZZATO-DA-GLÓRIA, B.; CARMELLOGUERREIRO, S.M. Anatomia vegetal. 2.ed. Viçosa: UFV, 2006. cap.12, p.303-326.

METCALFE, C.R.; CHALK, L. Anatomy of the dicotyledons: systematic anatomy of the leaf and stem. $2^{\text {nd }}$ ed. Claredon: Oxford University Press, 1979. v.1, 288p.

OLIVEIRA, J.D.; ALVES, C.C.F.; MIRANDA, M.L.D.; MARTINS, C.H.G.; SILVA, T.S.; AMBROSIO, M.A.L.V.; ALVES, J.M.; SILVA, J.P. Rendimento, composição química e atividades antimicrobiana e antioxidante do óleo essencial de folhas de Campomanesia adamantium submetidas a diferentes métodos de secagem. Revista Brasileira de Plantas Medicinais, Campinas, v.18, n.2, p.502-510, 2016.

PACHECO-SILVA, N.V.; DONATO, A.M. Morphoanatomy of the leaf of Myrciaria glomerata. Revista Brasileira de Farmacognosia, Curitiba, v.26, n.1, p.275$280,2016$.

PAIVA, J.G.A.; FANK-de-CARVALHO, S.M.; MAGALHÃES, M.P.; GRACIANO-RIBEIRO, D. Verniz vitral incolor 500: uma alternativa de meio de montagem economicamente viável. Acta Botânica Brasílica, Belo Horizonte, v.20, n.2, p.257-264, 2006.

PEIXOTO, J.R.V.; FAVORETO, C.J.R.; LIMA, A.O.; RIBEIRO, B.A.L. Levantamento florístico das mudas de restinga produzidas no Horto Restinga no município do Rio de Janeiro, RJ, Brasil. Revista Internacional de Ciências, Rio de Janeiro, v.5, n.2, p.96-112, 2015.

RAMOS, L.G.Q.; COTTA, E.A.; FONSECA FILHO, H.D. Análise morfológica das folhas de Anacardium occidentale. Biota Amazônia, Macapá, v.6, n. 1, p.16-19, 2016.

RETAMALES, H.A.; SCHERSON, R.; SCHARASCHKIN, T. Foliar micromorphology and anatomy of Ugni molinae Turcz. (Myrtaceae), with particular reference to schizogenous secretory cavities. Revista Chilena de Historia Natural, Santiago, v.87, n.27, p.1-7, 2014.

SÁ, R.D.; SANTANA, A.S.C.O.; RANDAU, K.P. Caracterização anatômica e histoquímica das folhas de Eugenia uniflora L. Journal of Environmental Analysis and Progress, Recife, v.1, n.1, p.96-105, 2016. 
SANTOS, J.W.; ALMEIDA, F.A.C.; BELTRÃO, N.E.M.; CAVALCANTI, F.B. Estatística experimental aplicada. 2.ed. Campina Grande: Embrapa Algodão/UFCG, 2008. $461 \mathrm{p}$.

SILVA, G.B.M.; PEDRONI, F. Frugivoria por aves em área de cerrado no município de Uberlândia, Minas Gerais. Revista Árvore, Viçosa, MG, v.38, n.3, p.433442, 2014.
SILVA, L.M.; ALQUINI, Y.; CAVALLET, V.J. Interrelações entre a anatomia vegetal e a produção vegetal. Acta Botânica Brasílica, Belo Horizonte, v.19, n.1, p.183-194, 2005.

SUTCLIFE, J.F. As plantas e a água. São Paulo: EPU/ EDUSP, 1980. 126p.

VIEIRA, S. Introdução à bioestatística. 4.ed. Rio de Janeiro: Elsevier, 2011. 360p.

WILLMER, C.; FRICKER, M. Stomata. 2.ed. Londres: Chapman \& Hall, 1996. 392p. 